\title{
Pre-commercial Procurement and the Marketing of Innovation: A New Innovation Policy Instrument or "Old Wine in New Bottles"?
}

\author{
Valeria De Bonis ${ }^{1} \&$ Alessandro Gandolfo ${ }^{2}$ \\ ${ }^{1}$ Department of Law, Philosophy and Economic Studies (DiGEF), Sapienza University of Rome, Rome, Italy \\ ${ }^{2}$ Department of Economics and Management (DEM), University of Pisa, Pisa, Italy \\ Correspondence: Valeria De Bonis, Department of Law, Philosophy and Economic Studies (DiGEF), Sapienza \\ University of Rome, Rome, Piazzale Aldo Moro 5, 00185 Rome, Italy. Tel: 39-06-4991-0727.
}

$\begin{array}{ll}\text { Received: September 7, } 2018 & \text { Accepted: October 3, } 2018 \quad \text { Online Published: November 24, } 2018 \\ \text { doi:10.5539/ijms.v10n4p39 } & \text { URL: https://doi.org/10.5539/ijms.v10n4p39 }\end{array}$

\begin{abstract}
We analyse the peculiarities of pre-commercial procurement (PCP) within the EU innovation policy kit, interpreting it as a risk-shifting mechanism. While most studies assume the point of view of the public procurer, we take the suppliers' one, with a focus on SMEs. We conclude that PCP, operating in the phase of the specification of technical requirements, has the peculiar role of favouring a better match between supply and demand as for innovative goods and can allow exploiting the competitive advantages that SMEs display in the early phases of the technological process, if interpreted as an innovation-leaking process.
\end{abstract}

Keywords: marketing of innovation, competition, public procurement for innovation, pre-commercial procurement, SMEs

\section{Introduction}

A new consensus has emerged at EU level on the importance of demand-side policies as an engine for innovation (European Commission 2005, 2006, 2014a). This has stemmed from the empirical results on their effectiveness (Nelson, 1982), and in comparison with supply-side instruments (Guerzoni \& Raiteri, 2015; Aschoff \& Sofka, 2009).

The new approach places an emphasis on the slowdowns and interruptions of the innovation process that can happen after investment in experimental research has occurred and before the commercialization phase has been reached.

The research and innovation life cycle whereby an idea is transformed into a viable marketable product (or service) is traditionally divided into four phases: phase 1 consists of the exploration of solutions and feasibility studies; phase 2 covers R\&D activity up to the creation of prototypes; in phase 3, through continued R\&D the first pre-series batch of pre-commercial volumes of pre-products is produced in order to carry out a field test that will then validate the product (or not); phase 4 sees the production and commercialization of large scale volumes of the product take place. The R\&D risk level usually decreases progressively through the four phases assuming value " 4 " at the beginning of the first phase and reaching " 0 " at the end of phase 4 (European Commission, 2006).

Because of the new policy approach, instruments that address phases after experimental research (basic research subsidies) and before commercialization (public procurement for innovation, PPI, previously called public technology procurement) have entered the European Commission innovation policy kit, and these include pre-commercial procurement (PCP).

PCP is a kind of procurement of R\&D services aimed at stimulating R\&D activity in the period before the production of prototypes or first-test series and without entailing the commitment to buy innovative commercial products. Because of its intermediate position between supply-(research subsidies) and demand-side (commercial public procurement) measures, it has been defined as the 'missing link' in the EU innovation cycle (European Commission, 2006). Part of the literature has, however, been reluctant to accept this interpretation, considering it either among demand-side or supply-side policy tools (Edquist \& Zabala-Iturriagagoitia, 2015).

The new policy paradigm especially targets small and medium sized enterprises (SMEs). Though PCP is not 
directly addressed to SMEs, its antecedents are the US SBIR and the UK SBRI programmes, both of which were specifically tailored for small firms. Moreover, EU documents often refer to the opportunities that PCP can offer to SMEs (European Commission, 2006, 2011, 2014a). The connection between innovation and SMEs is not new within EU policies: the 1986 SME Action Programme contained measures aimed at improving the competitiveness of SMEs by enhancing their ability to innovate; the issue was revisited in the Lisbon Strategy and in the Small Business Act (European Commission, 2008, 2009a). Nevertheless, the effectiveness of PCP in supporting innovation in SMEs is questionable (Cepilovs, 2012).

Against this background, we review the existing literature and policy documents on innovation marketing to address the question whether PCP is an effective tool to stimulate marketable innovation in a SMEs perspective. We first focus on the specific role that SMEs can play in the innovation process and at the market failures that can hinder it (section 2.1). We then review the literature on the limitations that traditional public commercial procurement faces (section 2.2). Based on this, we analyse whether PCP represents a more effective alternative for stimulating innovation and growth skills in SMEs (section 3), given its structure as deriving from the EU legal framework (section 4). The final section comments on the results and their policy implications.

\section{Literature Review}

\subsection{Innovation and SMES}

In the nineties, the Swedish economy proved unable to deliver innovative products despite its remarkably high commitment to R\&D. Edquist and McKelvey (1998) coined the term the 'Swedish paradox' to describe the phenomenon which a few years later was also detected in the German economy (Kuhlmann, 2003). In fact, the incapacity to translate top scientific performance into marketable innovation represented a widespread European problem. It could be argued that one of the causes of the EU paradox is the delay of SMEs compared to their US counterparts, as one comes to productivity and innovation (European Commission, 2009a, 2014a). European SMEs reveal lower innovative capacity than their US counterparts since most of them do not survive very long (Santarelli \& Vivarelli, 2007). The relevance of the performance of SMEs to economic policy appears obvious, if one considers that they are the prevalent form of business organisation in the EU (Cepilovs, 2012). Moreover, the economic literature has recognised the substantial role that SMEs can play in the economy as a source of innovative activity (Thurik, 1996; Noteboom, 1994; Burrone \& Jaiya, 2005; Audretsch, 2002) and a stimulus for economic development (Biggs, 2002; Newberry, 2006), industrial growth and job creation (Acs \& Audretsch, 1987), entrepreneur development (Johnson \& Cathcart, 1979) and increased competitiveness (Song \& Perry, 1997). It follows that enhancing the possibility for innovation to occur at the SME level could result in a widespread positive effect on the economy as a whole. Innovation deadlocks specific to SMEs have thus been addressed (European Commission, 2011).

The 'European paradox' marked the shift from the 'science-technology paradigm' to the 'innovation paradigm' in EU policy making. The traditional approach to innovation policy was based on the idea that firms' ability to innovate rested on the amount of investment in R\&D. This is typically less than socially optimal, because of market failure instances connected to the characteristics of scientific knowledge and technological development. This approach dates to Arrow (1962) and Schumpeter (1975) and provides the theoretical rationale for the granting of intellectual property rights (IPRs) and the public funding of R\&D.

The European paradox, however, showed that R\&D investment is not a sufficient condition for innovation. At the beginning of the new millennium, European policy making turned to a new theoretical rationale, provided by the literature on national innovation systems (Lundvall, 1992; Nelson, 1993; Lundvall \& Borràs, 1997). The new perspective focusses on systemic and institutional aspects of innovation and on the firms' learning process. It identifies typologies of market failure other than those related to the properties of scientific knowledge. These include failure in the provision of infrastructures, transition failure, and lock-in failure (Smith, 2000) and learning failure, exploitation-exploration and variety-selection trade-off, appropriability traps and complementarity failure (Malerba, 2002).

The innovation paradigm literature also emphasises the role of the users of innovation in its generation, development and diffusion, with reference to lead (von Hippel, 1986), sophisticated (Malerba et al., 2007) and experimental (Rogers, 1962) users and to the demand driven effects stemming from the interactions between innovative firms and innovative users (Lundvall, 1985; Malerba, 2007). Thus, innovation policy shifted from the emphasis on supply-side measures to a more comprehensive approach, based on a mix of supply and demand instruments. Among the latter, PPI became a systemic policy, aiming at pulling innovation through the demand for new products and solutions (Porter, 1990; Edler \& Georghiou, 2007; European Commission, 2003, 2005, 2006). 
The new paradigm also focuses on the place of SMEs within innovation policy, since they are considered strong players in knowledge intensive sectors, with cost effective R\&D activity and the capability to transform research results into marketable products. This is because SMEs appear to have a comparative advantage over large enterprises (LEs) due to their flexibility and customisation of products in the early, fluid phases of the technological cycle (Utterbach \& Suarez, 1993; Rothwell \& Zegveld, 1982). It is also recognised that they are more capable to 'catch' individual consumers and to increase the range of products and are able to enter markets in which economies of scale are absent and that are, therefore, left aside by larger enterprises. On the other hand, SMEs are at a disadvantage in the later, crystalized phases of the technological cycle, when standardisation is associated to gain from scale economies in production. Size related constraints are not associated with the production phase only. SMEs find it more difficult to attract funds than other innovative firms (European Commission, 2012, 2013), since financing SMEs is generally riskier than financing LEs (Berger \& Udell, 2005; Ayyagari et al., 2006; Beck et al., 2008). This is because size forces SMEs to concentrate on a small number of projects and this prevents them from differentiating and spreading risk. Also, scarcity of funds can hinder investment in R\&D facilities and in the employment of high-skilled workers (Acs \& Audretsch, 1990) and this often forces firms to restrict their search for new markets to local opportunities or at most to the national context, thus giving up the search for business opportunities in foreign markets.

Venture capital mitigates these problems (Engel, 2002), given its efficiency in operating under conditions of uncertainty and information asymmetries which characterise innovative projects in small and young firms (Caselli et al., 2008). However, venture capitalists concentrate on sectors with high perspective economic returns in the short- and medium-term. (Gans \& Stern, 2000), which leaves out the smallest, youngest and most experimental firms, especially if development costs are large and returns on investment are expected only in the long-term (Apostol, 2017).

Another mitigating factor could be getting access to knowledge and production networks (Zanfei, 1994); however, there is a lack of these between SMEs, as the latter usually limit their interactions to customers and local partners on the value chain (Kaufmann \& Toedtling, 2002).

When markets fail to deliver the right incentives, there is scope for public intervention to overcome innovation deadlocks.

\subsection{PPI and SMEs}

Size generates a trade-off between flexibility and availability of resources that reduces the likelihood that SMEs will engage in innovation activities. Public intervention can represent an option to not lose the advantages deriving from the peculiarities of SMEs, if it is tailored to their innovation potential. The literature shows that this lies in their ability to adapt to users' needs and this is important in the fluid phase of the innovation cycle. Policy should target the early stages of the technological process (Dalpé et al., 1992; Mazzucato, 2011). For instance, it could support the creation of knowledge and production networks to encourage SMEs to pool their R\&D facilities and work forces; or support the creation of venture capital funds aimed at financing innovation in SMEs. Also, in the presence of hindrances on the demand side, the government could take the role of a lead or experimental user (Georghiou, 2006). This could be done through public procurement for innovation (Edquist \& Hommen, 1998). A public agency could play the role of 'quality leader', acting, for instance, as an experimental user in the early stages of product cycles, when technical uncertainty is high (Malerba et al., 2007; Uyarra \& Flanagan, 2009) and commercial volumes do not reach the critical mass necessary to reach the break-even point. A classic example of successful public procurement for innovation is the development of the semiconductor industry in the US in reaction to stimulus from the Department of Defence (Rothwell, 1994). In markets with important societal needs (Edquist \& Hommen, 1998; Jaffe et al., 2004; OECD, 2014), the government might intervene to organise demand, through the specification of requirements based on socially desirable objectives. Successful examples include Japan's Rental Agency (JECC) with regard to the development of the domestic computer market and the NUTEK experience in Sweden (Nilson, 1994). In these cases, public procurement served as a catalyst, the motivation for intervention being to stimulate demand rather than to improve the provision of a public service (Note 1).

Public agencies also provide credibility to small firms (Edler \& Georghiou, 2007), thus helping them in entering markets for innovation.

The conditions under which PPI can lead to innovation (Geroski, 1990; Rothwell \& Zegveld, 1981; Uyarra et al., 2014) can, however, be at odds with those facilitating the access of SMEs to public tenders.

Successful PPI requires an 'intelligent' cooperation between customer and supplier (European Commission, 2005). SMEs are at a disadvantage from this point of view, since they lack an extensive network (Woldesenbet \& 
Worthington, 2018) and experience in dealing with the public sector. The structure of the procurement process is perceived as complex (Glover, 2008; Woldesenbet \& Worthington, 2018), beginning with the possibility of getting to hear of the call, which is reported as being difficult to obtain for SMEs which lack previous contracts with the public agency (European Commission, 2005). Easing SMEs' access can be obtained by the streamlining of bureaucratic procedures and the provision of information (GHK, 2010), for instance using national portals that allow public agencies to advertise tender opportunities and of streamlined pre-qualifications for use by SMEs (European Commission, 2005). However, recent experiences of using electronic solutions to carry out the procurement process have resulted in a large market share of contracts for SMEs, but contracts of low monetary value, reflecting what happens in physical markets (Albano et al., 2015).

Also, while the bundling of demand and use of selection criteria privileging size or experience are procurer's risk management techniques, they might make it difficult for SMEs to participate and win (Cabral et al., 2006; European Commission, 2008). This reduces the chance of successful market entry and overall innovation, when the latter comes through young, small firms, since large bundles give an advantage to large and mature incumbents (European Commission, 2005). Possible solutions are (European Commission, 2005): i) co-sourcing, that is, awarding the contract to more than one firm, thus also maintaining technological competition (Cabral et al., 2006); ii) multiple slots, in case the presence of scale economies is dubious, so that, if they are not, SMEs have an opportunity to bid and win; iii) availability of subcontracting, which entails, however, a minor role for SMEs within the public procurement market.

\section{The Case for PCP}

Overcoming the barriers that SMEs experience in accessing public procurement is among the reasons for introducing PCP (European Commission, 2006, 2011, 2014a). Though open also to LEs, the design of PCP is similar to that of the US SBIR programme (one should also note that in the US companies with less than 500 employees are considered 'small', whereas in the EU the limit is 50 for 'small' and 250 for 'medium' enterprises-European Commission, 2009b).

PCP is a kind of procurement of R\&D services by which the public procurer shares and limits the risk and the effort to pull R\&D activities until the production of a prototype or first test series is achieved, without entailing the commercial procurement of products that are ready for the market. Since information improves and uncertainty declines over the course of the innovation cycle, separating the initial activities from the rest of the procurement process considerably reduces risk, allowing the public procurer to test the innovative products before ordering them on a large scale.

There are also specific reasons for the adoption of the instrument in the context of EU innovation policies. First, deregulation and the subsequent loss of the monopsonistic power of old state monopolies, especially in the telecommunications, transport and energy sectors, has weakened the demand pull. This has meant that the role that public procurers used to play as first buyers in their interactions with private suppliers of intermediate goods no longer exists (European Commission, 2006). Second, the pre-commercial nature of PCP exempts it from national treatment and non-discrimination obligations under art. XV GPA WTO and from the general prohibition of state aid under art. 87 (1) of the EC Treaty, provided that the procedure guarantees competition and transparency and that risks and benefits be shared at market conditions between the public procurer and the supplier of R\&D services (Note 2).

Abiding by the EU and international legal norms in force creates a model of PCP with a specific structure. Its main characteristics are: a) the separation between the $R \& D$ phase and the phase of the production of commercial products, $b$ ) the sharing of risks and benefits at market conditions, c) the competitive development in phases (Ramboll, 2008). Like the US SBIR and the UK SBRI programmes, PCP is a model of competitive funnelling. It is a single procedure, with specific contracts for each phase (phase 1, exploration of solutions; phase 2, construction of prototypes and phase 3, production of first test series) of the innovation process and two points of intermediate evaluation. At the end of phase 1 and of phase 2, the best projects are selected and go on to the next step. It is thus a phased process with multiple suppliers, who participate in a selection process at the end of which the (eventual) commercial tender might be won by firms that have not participated in the pre-commercial phase (Figure 1). 


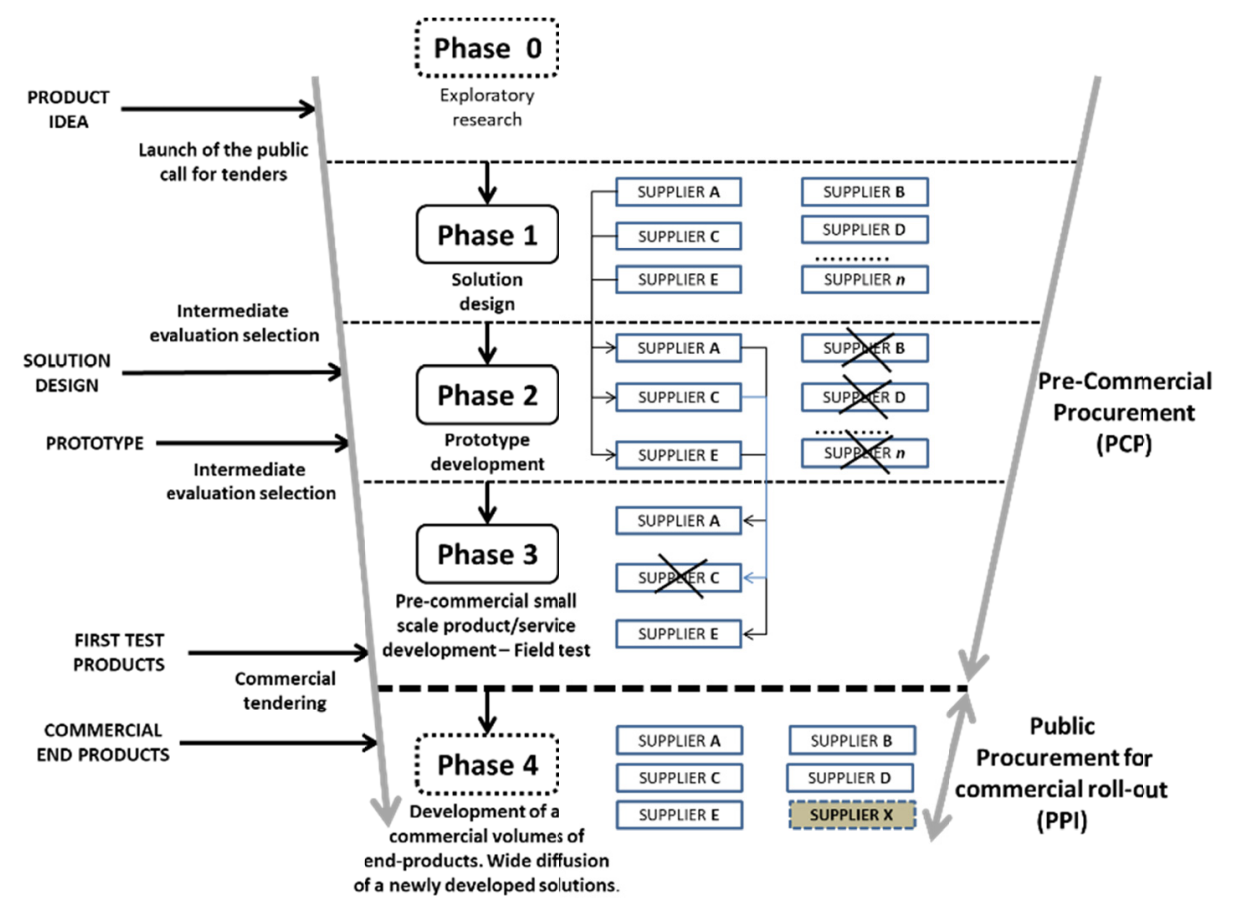

Figure 1. The PCP competitive funnelling process

Source: adapted from Blay (2014, p. 3).

The question we address in the following section is whether this structure is compatible with the aim of filling the gaps left by other supply- and demand-side innovation policy measures for SMEs.

\section{The Structure of PCP and Participation Incentives: The SMEs' Perspective}

\subsection{The Separation from the Commercial Phase}

The separation from the commercial phase distinguishes PCP from public procurement for innovation: while in the latter case the public agency acts as a lead customer by procuring the innovative solutions (and is a very important complement to PCP to ensure wide take up of newly developed pre-commercial R\&D pre-products), the former is a procurement of R\&D services needed for a technologically demanding solution that does not exist yet. Activities undertaken within PCP involve more risk than in the case of innovation procurement; this is true both in terms of technological risks (they require earlier stage $R \& D$, prototyping, testing, etc.) and in terms of non-technological risks (higher levels of uncertainty in the amount and timing of perspective returns and in cost estimations, etc.). PCP allows for the evaluation of alternative solutions, comparing prototypes and validating new designs in real field tests, before engaging in tenders for large scale deployment.

The separation from the commercial phase can entail advantages for SMEs. Though their involvement does not constitute a factor of success, easing the access to public procurement is an aim of EU innovation and industrial policies. This is because the flexibility of SMEs and, in some cases, the fact that their production is of a specialised nature or that they operate in niche markets that are neglected by large firms, means that they can offer solutions that LEs are unable to provide. However, size related difficulties can hinder participation in public tenders. PCP can represent a solution, since R\&D contracts are typically smaller in value and volume than commercial ones, given that they only require the production of a small quantity (e.g., one prototype or one first test series). Unbundling through PCP has had positive effects on SMEs' participation (Che et al., 2015). Moreover, company selection criteria related to financial stability and customer references, that are common in PPI procedures, do not hinder the participation of SMEs. Thus, SMEs should not encounter major size-related difficulties and in fact Bedin et al. (2015) report that PCP has actually increased the participation of SMEs.

Having said this, the separation from the commercial phase leaves the risks connected to it with the suppliers. In fact, the separation between the procurement of R\&D services and the procurement of innovative goods is a risk management tool for procurers, allowing them to de-risk large deployment contracts; moreover, the re-opening 
of competition in the commercial phase ensures the best value for money. These two effects are to the advantage of the public procurer, in that they limit the degree of risk that is shifted from the seller to the buyer. By the same token, however, leaving a significant part of the risk on the supply-side, this can discourage participation, especially by firms that are small, young and have no experience in public tenders.

Another problem is that the separation from the commercial phase, especially in the case of catalytic procurement, might leave a gap between the characteristics of the product obtained in the R\&D phase and the quality/price ratio threshold required by the market for mass production. This is a case of innovation deadlock: suppliers having reached the level of technological 'know how' to produce innovative goods, but in a context where demand is lacking or not sufficiently articulated, so that the innovative solutions do not receive the investment necessary to be materialized into successful products. Another factor which can contribute to the deadlock is that obtaining funds is particularly difficult at this stage: public support is no longer available, as the product is beyond the research phase, and private support is not yet available as the product is still in the pre-commercial phase. A typical example of this is the above-mentioned case of energy saving technologies that encountered problems.

SMEs, on the one hand, can benefit from the reduced contract scale, but, on the other hand, their participation might be discouraged by the difficulties that remain at the point when the innovation should reach the market. In fact, they might foresee their weaker position vis-à-vis large firms in the commercial tender.

Striking a balance between the pros and cons for SMEs of procuring R\&D only up to the phase of prototyping is possible if the public procurer considers the pre-commercial phase and the commercial one as distinct, but not separate. That is, the procurement process should envisage financial and non-financial support tools, following PCP and helping SMEs to reach the commercial phase, or, at least, allowing them to recover the costs incurred in the pre-commercial phase if they do not win the commercial tender.

Size-related difficulties can be summarised as deriving from scarcity of funds and or human resources. Therefore, SMEs that have already participated in PCP should be given the opportunity of access to dedicated venture capital funds (Note 3) (as in the US SBIR) and to the contact network of the public procurer. Prior to this, a form of support could be to assist SMEs to create a solid business plan, a necessary prerequisite for finding financial support for the marketing of their products.

\subsection{Competitive Development in Phases}

There are, however, other aspects of the PCP procedure that can promote the participation of SMEs (European Commission, 2006), counterbalancing the problems and enhancing the advantages of the separation from the commercial phase. PCP is, in fact, also characterised by a competitive development in phases.

PCP covers the innovation cycle until the point when the new products are tested to ensure that they comply with the functional requirements requested by the procurers. Limiting the amount of money awarded at each phase can deter LEs from applying to PCP tenders (Apostol, 2012). The size of the tasks and the value of the contract typically increase as the project develops so enabling SMEs to prepare for large-scale production. In the perspective offered by Malerba et al. (2007), they have time to develop the product to meet the market quality threshold level and, in this way, PCP can be used to break the lock-in deriving from the presence of sophisticated buyers. Moreover, PCP allows SMEs to gradually increase the financial requirements necessary to perform the task, so that they grow as entities, alongside the innovation project that they are driving. This is a chance for SMEs to step out of their traditional subcontractor role.

The fact that development occurs in phases also means it is a competitive process. Competition and the presence of more than one firm should guarantee supply, prevent monopoly and ensure better value for money and more creativity. These are advantages in the interests of both the public procurer and society as a whole. However, competition can reduce the suppliers' incentives to participate in the procedure. There are several obstacles that can hinder the participation of a plurality of competing firms, which might explain the empirical finding that PCP has not been effective in decreasing prices with respect to other forms of procurement (Bedin et al., 2015). Some of these obstacles are, however, more relevant for the LEs context than that of SMEs or can be alleviated by SMEs' participation. First, there may be few suppliers in the relevant sectors: securing SMEs participation is thus particularly important (Yukins \& Piga, 2012). Second, the funding initially available for each participant might be lower than in projects without multiple suppliers (whereas from the procurer's perspective, multiple suppliers can mean higher initial costs, but these will be recovered since the price will be lower under competitive conditions): this is more a disincentive for LEs than for SMEs, as argued above. Another disincentive may derive from the possibility that rivals gain disclosure to industrial secrets. Finally, due to the separation from the commercial phase, the winners of the pre-commercial phase do not necessarily obtain the 
contract for large scale deployment. This might imply that the commercial tender is won by a non-innovating firm, which reduces the incentive to participate in the pre-commercial tender.

The obstacles that may hinder the presence of a multiplicity of suppliers must be tackled with ad hoc measures, since competitive development is a crucial feature of PCP. First, each supplier should typically maintain IPRs, so that even those who do not pass to the successive phases can benefit from their investment in R\&D. Second, the business plan should be reconsidered at the end of each phase, to ensure that all potential benefits are reaped. Finally, the degree of risk sharing should be different in the different phases, with the procurer endorsing most of the costs in the initial phase. It should also be noted that SMEs that have undergone competitive development and had a first customer testing validating their solutions have increased credibility (Edler \& Georghiou, 2007). This in turn increases their ability to compete globally and to attract venture capitalists, as for instance, in the NHS UK case (European Commission, 2014b).

\subsection{The Sharing of Risks and Benefits}

Risks deriving from the separation from the commercial phase and the competitive nature of PCP must be counterbalanced by awarding producers a larger share of the benefits of the innovation process. This economic reason, besides the legal restrictions on state aid explains the shared risks - shared benefits approach, based on agreements on the assignment of IPRs. This element is an important step in the innovation cycle. In one of the most famous examples of private technology procurement, the cooperation between Toyota and Nippon Steel (Hellman, 1993; Edquist \& Hommen, 1998), which led to an innovation in the steel industry in 1983, an agreement on the exploitation of research results preceded the beginning of large-scale production. PCP does not involve an exclusive use of research results by the public procurer, but these are typically shared with suppliers and other stakeholders (for instance, another public procurer). This feature is directly linked to the fact that research results are not commercial products yet.

IPRs are a key benefit of R\&D projects and therefore of risk-benefit sharing. Moreover, they are strictly connected to the presence of multiple suppliers and to the other key factors that make PCP of interest to SMEs.

The problem of the assignment of IPRs can be identified with respect to its two extreme solutions: a) assigning IPRs to the supplier involves the risk of a vendor lock-in situation for the procurer, who has borne the product development costs; b) assigning the IPRs to the procurer reduces the incentive to innovate and to share risk, and so does not allow the supplier to exploit the innovation in the market.

IPRs sharing can ensure that both the public procurer's and the supplier's fundamental needs are met. The procurer should be able to freely apply the innovation, directly using it or licensing it to other producers to guarantee competition. The supplier on the other hand should be able to commercially exploit it with other customers. In PCP, IPRs are attributed either to the procurer or to the supplier in a non-exclusive way. In the first case, the public procurer allows the supplier to commercialise products, thus obtaining risk sharing, through a price reduction or a participation in the costs of managing IPRs. In the second case, as in the US SBIR, the procurer keeps the right to freely use the innovation or to license it to third parties (or to require the supplier to license it to third parties at market conditions).

The degree of sharing should depend on the contribution that each party has given to the development of the innovation and on the ability to exploit IPRs. In general, the more innovative the solution and the larger the investment required, or the higher the probability of commercial exploitation and future improvements, the more IPRs should be left with the market. Instead, the higher the risk of vendor lock-in and uncertainty, the more IPRs should be left with the public procurer (European Commission, 2007).

Of course, the participation in the tender is less attractive if fewer rights are granted to the supplier. From the public procurer's point of view, the right to use the innovation, to let other parties use it and to obtain a return for letting others use it, is granted both by entitling the public procurer with the IPRs and by leaving them with the supplier but granting the public procurer a licence. The procurer's intent to limit the use of the innovation by third parties is obtained by assigning the IPRs to the public procurer or by assigning them to the supplier but granting the public procurer an exclusive licence.

Leaving the IPRs with the supplier is essential for SMEs and can change the configuration of the competitive funnelling process to be to their advantage, on the one hand, reducing the share of risk borne by them, and, on the other hand, giving them a chance to grow globally by reselling solutions to other markets (European Commission, 2014b).

One thing needs to be stressed within this contextual framework: suppliers should be able to license the IPRs resulting from the R\&D activities undertaken within the project to both other participating firms and external 
ones even before the end of the procedure. In this way the SMEs could recover the revenue that they have invested in the innovation sooner. This could certainly incentivise them to invest as SMEs are often undercapitalised and lack economic and financial resources.

Besides reducing risk, another positive effect of this open modality would be the increased interactive activity between innovative firms: licensors and licensees could exchange knowledge about technology and markets. Participation in a network is often difficult for SMEs and an open vision of PCP could favour it. This enlarged interpretation of the competitive process according to an open modality (Figure 2), besides strengthening the feature of risk reduction typical of PCP, could generate a systemic effect on the industrial sector of a country, insomuch as increased interactions among firms favour the growth in size of SME's. The competitive funnel could leak out innovation before the procedure ends and innovative solutions could leak into it through the relationships created between participating firms and others external to the process.

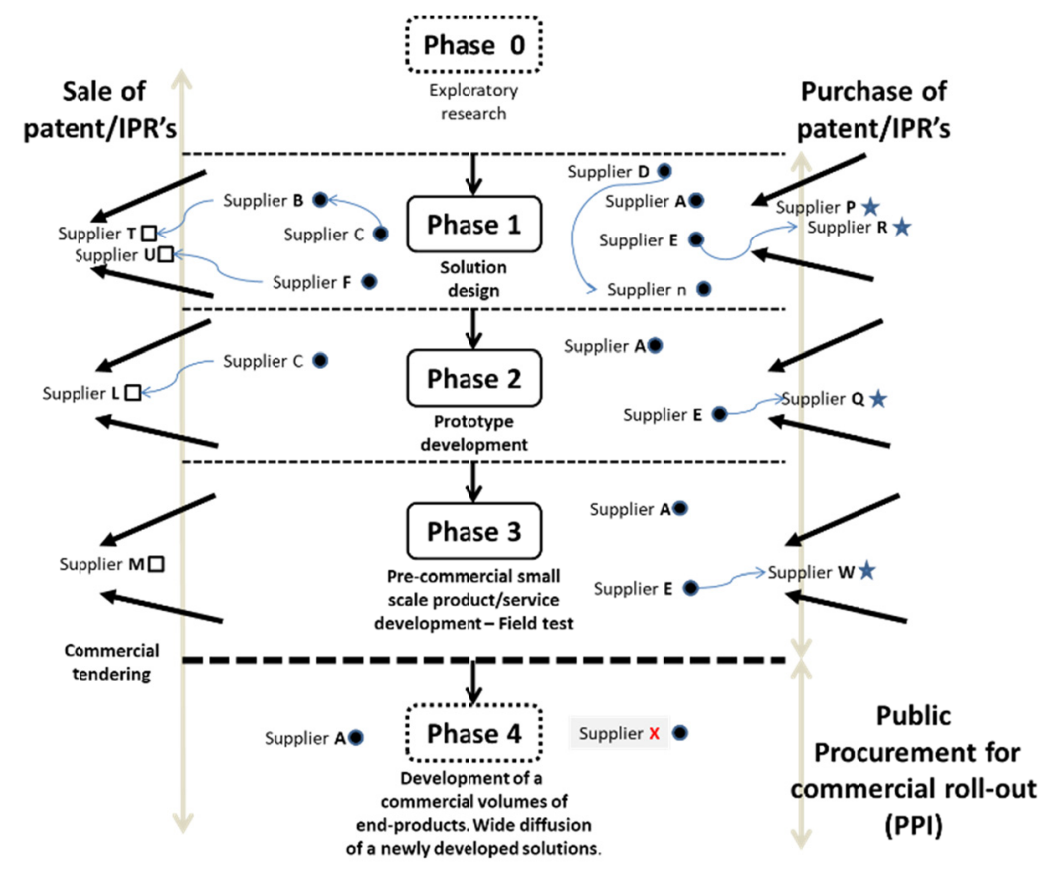

Figure 2. PCP as an innovation-leaking funnel

In addition, the procurer would benefit from the improvements in innovative solutions that could be incorporated into the prototype or the projects. At the end of the PCP procedure, the procurer could obtain a better output, deriving from the innovative efforts of a number of firms that is larger than that of official participants.

\section{References}

Acs, Z. J., \& Audretsch, D. B. (1987). Innovation, Market Structure and Firm Size. Review of Economics and Statistics, 69, 567-574. https://doi.org/10.2307/1935950

Acs, Z. J., \& Audretsch, D. B. (1990). Innovation and small firms. London: MIT Press.

Albano, G. L., Antellini-Russo, F., Castaldi, G., \& Zampino, R. (2015). Evaluating Small Businesses' Performance in Public e-Procurement: Evidence from the Italian Government's e-Marketplace. Journal of Small Business Management, 53, 229-250. https://doi.org/10.1111/jsbm.12190

Apostol, A. R. (2012). Pre-commercial procurement in support for innovation. Regulatory effectiveness? Public Procurement Law Review, 21, 213-225.

Apostol, R. (2017). Trials and tribulations in the implementation of pre-commercial procurement in Europe. Asse Press-Springer.

Archibald, R. B., \& Finifter, D. H. (2003). Evaluating the NASA Small Business Innovation Research Program: Preliminary Evidence of a Trade-Off between Commercialization and Basic Research. Research Policy, 32, 605-619. http://dx.doi.org/10.1016/S0048-7333(02)00046-X 
Arrow, K. (1962). Economic welfare and the allocation of resources for inventions. In R. R. Nelson (Ed.), The rate and direction of inventive activity. Princeton, NJ: Princeton University Press.

Aschoff, B., \& Sofka, W. (2009). Innovation on demand. Can public procurement drive market success of innovation? Research Policy, 38, 1235-1247. https://dx.doi.org/10.1016/j.respol.2009.06.011

Audretsch, D. B. (2002). The Dynamic Role of Small Firms: Evidence from the US. Small Business Economics, 18, 13-40. https://dx.doi.org/10.1007/978-1-4615-0963-9_2

Ayyagari, M., Demirgüç-Kunt, A., \& Maksimovic, V. (2006). How Important Are Financing Constraints? The Role of Finance in the Business Environment, Policy Research Working Paper Series, No 3820, The World Bank. https://dx.doi.org/10.1093/wber//hn018

Beck, T., Demirgüç-Kuntand, A., \& Maksimovic, V. (2008). Financing patterns around the world: Are small $\begin{array}{lllll}\text { firms different? Journal of Financial Economics, } & \text { 89, }\end{array}$ https://dx.doi.org/10.1016/j.jfineco.2007.10.005

Bedin, S., Decarolis, F., \& Iossa, E. (2015). Quantifying the impact of Pre-Commercial Procurement (PCP) in Europe based on evidence from the ICT sector. European Commission-DG Communications Networks, Content \& Technology.

Berger, A. N., \& Udell, G. F. (2005). A more complete conceptual framework for financing of small and medium enterprises, Policy Research Working Paper Series, No 3795, The World Bank.

Biggs, T. (2002). Is small beautiful and worthy of subsidy? Literature review, IFC.

Blay, M. A. B. (2014). The Strategic Use of Public Procurement in Support of Innovation. European Procurement \& Public Private Partnership Law Review, 9, 3-11.

Burrone, E., \& Jaiya, G. S. (2005). Intellectual Property (IP) Rights and Innovation in Small and Medium-Sized Enterprises. Geneva: World Intellectual Property Organization.

Cabral, L., Cozzi, G., Denicolò, V., Spagnolo, G., \& Zanza, M. (2006). Procuring Innovations. In N. Dimitri, G. Piga, \& G. Spagnolo (Eds.), Handbook of procurement. Cambridge: Cambridge University Press.

Caselli, S., Gatti, S., \& Perrini, F. (2008). Are venture capitalists a catalyst for innovation? European Financial Management, 15, 92-111. https://dx.doi.org/10.1111/j.1468-036X.2008.00445.x

Cepilovs, A. (2012). Public procurement of innovation and small and medium-sized enterprises. Aalborg: Aalborg University Press. https://dx.doi.org/10.1111/j.1468-036X.2008.00445.x

Che, Y. K., Iossa, E., \& Rey, P. (2015). Prizes vs Contracts as Reward for Innovation. Toulouse School of Economics.

Dalpé, R., De Bresson, C., \& Xiaoping, H. (1992). The public sector as a first user of innovation. Research Policy, 21, 251-263. https://dx.doi.org/10.1016/0048-7333(92)90019-Z

Edler, J., \& Georghiou, L. (2007). Public procurement and innovation-Resurrecting the demand side. Research Policy, 36, 949-963. https://dx.doi.org/10.1016/j.respol.2007.03.003

Edquist, C., \& Hommen, L. (1998). Government Technology procurement and innovation theory. Innovation Systems and European Integration, European Commission.

Edquist, C., \& McKelvey, M. (1998). High R\&D intensity without high-tech products: a Swedish paradox? In K. Nielsen \& B. Johannsen (Eds.), Institutions and economic change: new perspectives on markets, firms and technology. Cheltenham: E. Elgar.

Edquist, C., \& Zabala-Iturriagagoitia, J. M. (2015). Pre-commercial procurement: a demand or supply policy instrument in relation to innovation? $R \& D$ Management, 45, 147-160. https://dx.doi.org/10.1111/radm.12057

Engel, D. (2002). The impact of venture capital on firm growth: an empirical investigation. ZEW Discussion Paper No. 02-02.

European Commission. (2003). Commission Recommendation concerning the definition of micro, small and medium-sized enterprises. 2003/361/EC, Brussels: Commission of the European Communities. Retrieved from http://eur-lex.europa.eu/LexUriServ/LexUriServ.do?uri=OJ:L:2003:124:0036:0041:en:PDF

European Commission. (2005). Report of the Expert Group on Public Procurement for Research and Innovation. Directorate General for Research, September, Brussels: Commission of the European Communities. 
Retrieved

from

http://ec.europa.eu/invest-in-research/pdf/download_en/edited_report_18112005_on_public_procurement_f or_research_and_innovation.pdf

European Commission. (2006). Pre-commercial procurement of Innovation. A missing link in the European Innovation Cycle, March, Brussels: Commission of the European Communities, available at https://cordis.europa.eu/pub/ist/docs/pre-commercial_procurement_of_innovation.pdf

European Commission. (2007). Pre-commercial Procurement: driving innovation to ensure sustainable high-quality public services in Europe. Communication 799. Retrieved from https://eur-lex.europa.eu/legal-content/EN/TXT/?uri=CELEX\%3A52007DC0799

European Commission. (2008). Think small first, a Small Business Act for Europe, IP/08/1003, June 25, Brussels: Commission of the European Communities. Retrieved from http://europa.eu/rapid/press-release_IP-08-1003_en.htm

European Commission. (2009a). Report of The Expert Group on Think Small First-Considering SME interests in policy-making. Including the application of an SME Test', March, Brussels: Commission of the European Communities.

Retrieved

from https://ec.europa.eu/growth/smes/business-friendly-environment/small-business-act_it

European Commission. (2009b). Staff Working Document on the implementation of Commission Recommendation of 6 May 2003 concerning the definition of micro, small and medium sized enterprises, SEC 1350

European Commission. (2011). Proposal for a directive of the European Parliament and of the Council on public procurement. Brussels, COM (2011) 896 final.

European Commission. (2012). EU SMEs in 2012: at the Cross-Road, Rotterdam.

European Commission. (2013). SMEs' Access to finance. Brussels: Commission of the European Communities.

European Commission. (2014a). Public procurement as a driver of innovation in SMEs and public services. Brussels: Commission of the European Communities. Retrieved from http://ec.europa.eu/enterprise/policies/innovation/policy/public-procurement/index_en.htm

European Commission. (2014b). Frequently asked questions about PCP and PPI, Digital Single Market-Factsheet, 23 April 2014. Retrieved from https//ec.europa.eu/digital-single-market

Faucher, P., \& Fitzgibbons, K. (1993). Public demand and the management of technological risk in large-scale projects. Science and public Policy, 20, 173-185.

Gans, J., \& Stern, S. (2000). When does funding smaller firms bear fruit? Evidence from the SBIR program. NBER Working Paper No. 7877.

Georghiou, L. (2006). Effective innovation policies for Europe-the missing demand-side. In Economic Council Secretariat (Ed.), Globalisation challenges for Europe. Prime Minister Office Publications, Finland.

Geroski, P. A. (1990). Procurement policy as a tool of industrial policy. International Review of Applied Economics, 4, 182-198. https://dx.doi.org/10.1080/758523673

Ghisetti, C. (2017). Demand-pull and environmental innovations: Estimating the effects of innovative public

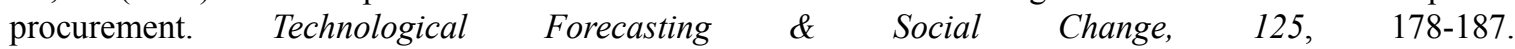
https://dx.doi.org/10.1016/j.techfore.2017.07.020

GHK. (2010). Evaluation of SMEs' access to public procurement markets in the EU. DG Enterprise and Industry, Brussels.

Glover, A. (2008). Accelerating the SME economic engine: Through transparent, simple and strategic procurement, London, HM Treasury.

Guerzoni, M., \& Raiteri, E. (2015). Demand-side vs supply-side technology policies: Hidden treatment and new empirical evidence on the policy mix. Research Policy, 44, 726-747. https://dx.doi.org/10.1016/j.respol.2014.10.009

Hellman, J.-L. (1993). Supplier-customer interaction in product development: A case study of Nippon Steel's cooperation with Toyota, Kunitachi. Tokyo: Hitotsubashi University, Institute of Business Research.

Jaffe, A. B., Newell, R. G., \& Stavins, R. N. (2004). A tale of two market failures. Technology and environmental policy. RFF DP 04-38, Washington: Resources for the Future, October. Retrieved from 
http://ageconsearch.umn.edu/bitstream/10815/1/dp040038.pdf

Johnson, P. S., \& Cathcart, D. G. (1979). The Founders of New Manufacturing Firms: A Note on the Size of Their 'Incubator' Plants'. Journal of Industrial Economics, 28, 219-224. https://dx.doi.org/10.2307/2098039

Kanz, J. W. (1993). Technology, globalization and defence: Military electronics strategies in a changing world. International Journal of Technology Management, 8, 59-76.

Kaufmann, A., \& Tödtling, F. (2002). How effective is innovation support for SMEs? An analysis of the region of Upper Austria, Technovation, 22, 147-159. https://dx.doi.org/10.1016/S0166-4972(00)00081-X

Kuhlmann, S. (2003). Evaluation of research and innovation policies: a discussion of trends with examples from Germany. International Journal of Technology Management, 26, 131-149. https://dx.doi.org/10.1504/IJTM.2003.003366

Kuhlmann, S. (2003). Evaluation of research and innovation policies: a discussion of trends with examples from Germany. International Journal of Technology Management, 26, 131-149.

Lerner, J. (1999). The government as venture capitalist: the long-run impact of the SBIR programme. Journal of Business, 72, 285-318. https://dx.doi.org/10.1086/209616

Lundvall, B.-Å. (1985). Product innovation and user-producer interaction, Industrial development research series no. 31. Aalborg: Aalborg University Press.

Lundvall, B.-Å. (Ed.). (1992). National systems of innovation: Towards a theory of innovation and interactive learning. London: Pinter Publishers.

Lundvall, B.-Å., \& Borràs, S. (1997). The globalising learning economy: implications for innovation policy. Report based on contributions from seven projects under the TSER programme DG XII. Brussels: Commission of the European Communities.

Malerba, F. (2002). Sectoral systems of innovation and production. Research Policy, 31, 247-264. https://dx.doi.org/10.1016/S0048-7333(01)00139-1

Malerba, F. (2007). Innovation and the dynamics and evolution of industries: Progress and challenges. $\begin{array}{llll}\text { International Journal of Industrial } & \text { Organization, 25, 675-699. }\end{array}$ https://dx.doi.org/10.1016/j.ijindorg.2006.07.005

Malerba, F., Nelson, R., Orsenigo, L., \& Winter, S. (2007). Demand, innovation, and the dynamics of market structure: The role of experimental users and diverse preferences. Journal of Evolutionary Economics, 17 , 371-399. https://dx.doi.org/10.1007/s00191-007-0060-x

Mansfield, E. (1968). Industrial Research and Technological Innovation: An Econometric Analysis. New York: W. W. Norton.

Mazzucato, M. (2011). The Entrepreneurial State, Demos. https://dx.doi.org/10.3898/136266211798411183

Nelson, R. R. (1982). Government and Technical progress: A Cross-Industry Analysis. Oxford: Pergamon Press.

Nelson, R. R. (Ed.). (1993). National systems of innovation: A comparative study. Oxford: Oxford University Press.

Newberry, D. (2006). The role of small and medium sized enterprises in the futures of emerging economies. World Resource Institute.

Nilson, H. (1994). Technology procurement for market transformation—a customer tool for sustainable design and manufacturing. Stockholm: NUTEK.

Noteboom, B. (1994). Innovation and diffusion in small firms: Theory and evidence. Small Business Economics, 6, 327-347. https://dx.doi.org/10.1007/BF01065137

OECD. (2014). Intelligent Demand: Policy Rationale, Design and Potential Benefits, OECD Science, Technology and Industry, Policy Papers, No. 13, OECD Publishing. Retrieved from https://dx.doi.org/10.1787/5jz8p4rk3944-en

Porter, M. E. (1990). The competitive advantage of nations. London: MacMillan.

Ramboll Management Consulting. (2008). Opportunities for Public Technology Procurement in the ICT-related Sectors in Europe. Final Report of the DG Information and Society, CE.

Rigby, J. (2016). The impact of pre-commercial procurement on innovation. In J. Edler, P. Cunningham, A. Gök, 
\& P. Shapira (Eds.), Handbook of Innovation Policy Impact. Cheltenham: Edward Elgar Publishing.

Rogers, E. M. (1962). Diffusion of innovations. New York: The New Press.

Rothwell, R. (1994). Issues in user-producer relations in the innovation process: the role of government. International Journal of Technology Management, 9, 629-649.

Rothwell, R., \& Zegveld, W. (1982). Industrial innovation and public policy. London: Frances Pinter.

Santarelli, E., \& Vivarelli, M. (2007). Entrepreneurship and the process of firms' entry, survival and growth. Industrial and Corporate Change, 16, 455-488.

Schmookler, J. (1966). Invention and Economic Growth. Cambridge, MA: Harvard University Press.

Schumpeter, J. A. (1975). Capitalism, Socialism and Democracy. New York: Harper.

Smith, K. (2000). Innovation as a systemic phenomenon: rethinking the role of policy. Enterprise \& Innovation Management Studies, 1, 73-102. https://dx.doi.org/10.1080/146324400363536

Song, M., \& Parry, M. (1997). A cross-national comparative study of new product development processes: Japan and the USA. Journal of Marketing, 61, 1-18.

Thurik, A. R. (1996). Introduction: Innovation and Small Business. Small Business Economics, 8, 175-176. https://dx.doi.org/10.1007/BF00388645

Utterback, J. M., \& Suarez, F. F. (1993). Innovation, competition and industry structure. Research Policy, 22, 1-21. https://dx.doi.org/10.1016/0048-7333(93)90030-L

Uyarra, E., \& Flanagan, K. (2009). Understanding the innovation impact of public procurement. Working Paper No. 574, Manchester Business School.

Uyarra, E., Edler, J., Garcia Estevez, J., Georghiou, L., \& Yeou, J. (2014). Barriers to innovation through public $\begin{array}{lllll}\text { procurement: } & \text { a } & \text { supplier } & \text { perspective. } & \text { Technovation, }\end{array} 4$. https://dx.doi.org/10.1016/j.technovation.2014.04.003

Vargas-Hernández, J. G., Noruzi, M. R., \& Sariolghalam, N. (2010). Risk or Innovation, Which One Is Far More Preferable in Innovation Projects? International Journal of Marketing Studies, 2, 233-244. https://dx.doi.org/10.5539/ijms.v2n1p233

Vasilescu, L. (2014). Assessing Finance for Innovative EU SMEs-Key Drivers and Challenges. Journal of Economics and Business, 12, 35-47.

Von Hippel, E. (1986). Lead users: a source of novel product concepts, Management Science, 32, 791-805. https://dx.doi.org/10.1287/mnsc.32.7.791

Woldesenbet, K., \& Worthington, I. (2018). Public procurement and small businesses: Estranged or Engaged? Journal of Small Business Management. https://dx.doi.org/10.1111/jsbm.12442

Yukins, C., \& Piga, G. (2012). Dialogue: Set-asides for Small and Medium Firms. In G. Piga \& S. Treumer (Eds.), The Applied Law and Economics of Public Procurement. London, Routledge.

Zanfei, A. (1994). Surviving Competition Through Cooperation. Journal of Industry Studies, 1, 65-76. https://dx.doi.org/10.1080/13662719400000004

Notes

Note 1. Ghisetti (2017) finds a positive effect of innovative public procurement in driving the adoption and diffusion of sustainable manufacturing technology. Of course, procurement is not the only public measure for innovation operating on the demand side - see Edler and Georghiu (2007) for a taxonomy.

Note 2. On the legal framework of PCP, see, among others, Apostol (2012).

Note 3. This appears particularly relevant, given the low impact that PCP has generally had in attracting financial investors (Bedin et al., 2015).

\section{Copyrights}

Copyright for this article is retained by the author(s), with first publication rights granted to the journal.

This is an open-access article distributed under the terms and conditions of the Creative Commons Attribution license (http://creativecommons.org/licenses/by/4.0/). 